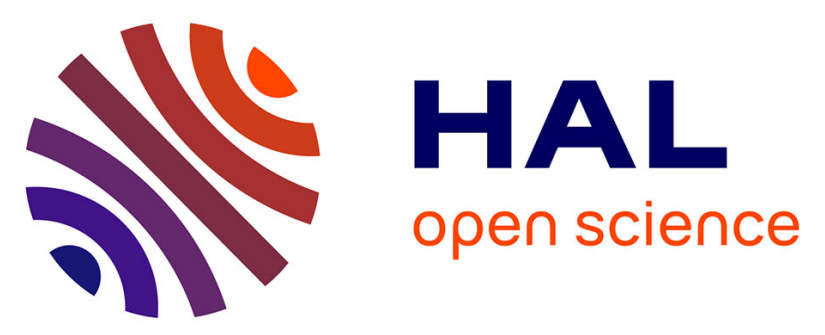

\title{
Carbon and strontium isotope ratios shed new light on the paleobiology and collapse of Theropithecus, a primate experiment in graminivory
}

Luke Fannin, Justin Yeakel, Vivek Venkataraman, Chalachew Seyoum, Denis Geraads, Peter Fashing, Nga Nguyen, Kena Fox-Dobbs, Nathaniel Dominy

\section{To cite this version:}

Luke Fannin, Justin Yeakel, Vivek Venkataraman, Chalachew Seyoum, Denis Geraads, et al.. Carbon and strontium isotope ratios shed new light on the paleobiology and collapse of Theropithecus, a primate experiment in graminivory. Palaeogeography, Palaeoclimatology, Palaeoecology, 2021, 572, pp.110393. 10.1016/j.palaeo.2021.110393 . hal-03328097

\section{HAL Id: hal-03328097 https://hal.science/hal-03328097}

Submitted on 19 Oct 2021

HAL is a multi-disciplinary open access archive for the deposit and dissemination of scientific research documents, whether they are published or not. The documents may come from teaching and research institutions in France or abroad, or from public or private research centers.
L'archive ouverte pluridisciplinaire HAL, est destinée au dépôt et à la diffusion de documents scientifiques de niveau recherche, publiés ou non, émanant des établissements d'enseignement et de recherche français ou étrangers, des laboratoires publics ou privés. 


\section{Carbon and strontium isotope ratios shed new light on the paleobiology and collapse of}

\section{Theropithecus, a primate experiment in graminivory}

Luke D. Fannin $^{\mathrm{a}, \mathrm{b}, *}$, Justin D. Yeakel ${ }^{\mathrm{c}}$, Vivek V. Venkataraman ${ }^{\mathrm{d}, \mathrm{e}}$, Chalachew Seyoum ${ }^{\mathrm{f}}$, Denis

Geraads $^{\mathrm{g}}$, Peter J. Fashing ${ }^{\text {h,i }}$, Nga Nguyen ${ }^{\text {h,i }}$, Kena Fox-Dobbs ${ }^{\mathrm{j}}$, Nathaniel J. Dominy ${ }^{\mathrm{a}, \mathrm{e}}$,

${ }^{a}$ Department of Anthropology, Dartmouth College, Hanover, NH 03755, USA

${ }^{\mathrm{b}}$ Ecology, Evolution, Environment and Society, Dartmouth College, Hanover, NH 03755, USA

${ }^{\mathrm{c}}$ School of Natural Sciences, University of California Merced, Merced, CA 95340, USA

${ }^{\mathrm{d}}$ Department of Anthropology and Archaeology, University of Calgary, T2N 1N4 Calgary, Canada

${ }^{\mathrm{e}}$ Department of Biological Sciences, Dartmouth College, Hanover, NH 03755, USA

${ }_{\mathrm{f}}$ Department of Pathology and Anatomical Sciences, University of Missouri, Columbia, MO 65211, USA

${ }^{\mathrm{g}}$ CR2P, Muséum National d'Histoire Naturelle, CNRS, Sorbonne Université, 75231 Paris Cedex 05, France

${ }^{\mathrm{h}}$ Department of Anthropology, California State University, Fullerton, CA 92834, USA

${ }^{\mathrm{i}}$ Centre for Ecological and Evolutionary Synthesis, Department of Biosciences, University of Oslo, NO-0316 Oslo, Norway

${ }^{\mathrm{j} D e p a r t m e n t}$ of Geology, University of Puget Sound, Tacoma, WA 98416, USA

*Corresponding author

Email: luke.d.fannin.gr@dartmouth.edu 


\begin{abstract}
The rise and spread of tropical grasslands was a signal event in the Cenozoic, causing many ungulates to evolve adaptations to a diet of graminoid tissues, or graminivory. In parallel, a lineage of monkeys (Theropithecus) is distinguished among primates for its large size and commitment to graminivory, a trait expressed by species throughout the Plio-Pleistocene fossil record and $T$. gelada, the sole surviving species today. An open question concerns the mechanics of how species handled graminoid tissues. They might have exhibited preference, selecting tissues within a tuft, or they might have practiced indiscriminate bulk-feeding in a manner similar to large grazing ungulates.. Variation in this behavior explains a significant amount of variation in body mass through time, and we describe these covarying traits, which peaked during the Pleistocene, as evolutionary traps. To support this characterization, we report evidence of temporal increases in strontium isotope variability among North African theropiths, a result that suggests greater lifetime travel and energetic costs in response to diminishing food resources, a probable factor in the extinction of $T$. oswaldi, the largest monkey that ever lived.
\end{abstract}

Keywords: C4 photosynthesis; African grasslands; primate evolution; stable isotope ecology; plant fracture toughness 


\section{Introduction}

Theropithecus is a genus of cercopithecid monkey that once flourished across Plio-Pleistocene Africa, southern Europe, and South Asia (). The sole surviving species is the gelada (T. gelada), which is today restricted to the Afroalpine grasslands of Ethiopia.Geladas subsist on graminoid tissues (57-97\% of foraging time; review: Fashing et al., 2014), including leaf blades, flowers, seeds, and underground corms and bulbs-Yet, a comparable level of graminivory is evident throughout the fossil record of the genus (Cerling et al., 2013), which is evident in the postcranium and cranium of Theropithecus. For example, it has derived forelimbs to enable the fine visuomotor control necessary for within grass (Jolly, 1972; Jablonski et al., 2002). This food is then reduced by thickly enameled, high-crowned molars with a cuspal pattern that increases in complexity during wear, thus maintaining an efficient grinding platform for reducing tough plant tissues (Jablonski, 1994; Venkataraman et al., 2014). Such dental anatomy bears a strong functional resemblance to the hypsodont teeth of grazing artiodactyls, but the convergence ends there. Geladas do not have the advantages of large body size or ruminant digestion (Dunbar and Bose, 1991).

The gastrointestinal tract of geladas has baboon- or human-like proportions, with some modest expansion of the caecum and large intestine (Hill, 1970; Mau et al., 2011). The absence of large fermentative chambers is a puzzle, and it has long motivated a question: How do geladas digest so much fibrous plant matter? Mau et al. (2009a,b) explored the issue in a population of captive geladas and found ruminant-like salivary proteins, a trait that should accommodate microbial cellulolysis) necessary for accessing cell contents. Mau et al. (2011) affirmed this prediction when they used the gastrointestinal microbiota (GIM) of captive geladas to ferment hay; 
however, the performance was comparable to the GIMs of zebras and hamadryas baboons. In another study, the GIMs of captive geladas were used to ferment potato and grass, but the performance was similar to those of human vegetarians (Frost et al., 2014). Thus, the GIMs of captive geladas and zebras are either surprisingly poor at microbial cellulolysis or those of baboons and humans are surprisingly effective. At the same time, the microbiomes of wild geladas are enriched in Fibrobacteres (100× the abundance in modern humans), a phylum strongly associated with cellulolysis (Trosvik et al., 2018).

Against this backdrop, it is useful to examine how geladas handle graminoid tissues, and how descriptions vary in the literature. Some authors describe geladas as selective graminivores to emphasize the manual motor precision behind their discerning diet (Jablonski and Leakey, 2008; Souron, 2018). It is a mechanistic term that could be misunderstood asness; however, the manual facility of geladas enables a wide range of edible tissues. On the Guassa Plateau of Ethiopia the diet includes leaves (50.6\%), underground storage organs $(4.0 \%)$, and seeds $(2.2 \%)$ of graminoid plants ( $=56.8 \%$ of the diet), in addition to forbs (37.8\%), invertebrates $(2.8 \%)$, and other items (2.6\%) (Fashing et al., 2014). It is analogous to the diets of medium-sized ungulate (termed intermediate feed by Hofmann, 1989), which complement graminoid tissues with those of browse and forbs (Jarman, 1974; Hofmann, 1989). Forbs are high-quality foods (Clauss et al., 2008b) that smaller geladas prefer when available (Fashing et al., 2014). Other populations of geladas devote $23-26 \%$ of their total feeding time to the storage organs and seeds of graminoid plants (Dunbar, 1977), a crucial resource when preferred foods are scarce (Jarvey et al., 2018).

Some authors describe geladas as bulk-feeders (Dunbar, 1983; Iwamoto, 1993), with a preference for the greenest or youngest grass blades (Dunbar and Bose, 1991). Bulk-feeding in 
this context is analogous to grazing, where food selection is indiscriminate and determined by

local availability (Jarman, 1974; Hofmann, 1989). Clauss et al. (2008a) divided bulk-feeding into two approaches. First is the "efficiency approach," which relies on long digestive retention times. Rumination exemplifies this approach, but it is constrained by the need for small particle sizes and is therefore sensitive to high fiber content (Janis, 1976; Clauss et al., 2009). Second is the “intake approach," which prioritizes rapid intake and throughput, coupled with greater chewing efficiency. Equids and geladas, for instance, ingest food faster and chew more efficiently than ruminant artiodactyls do (Venkataraman et al., 2014). The intake approach is more tolerant to fiber content, allowing zebras to consume more grass stems than wildebeests inhabiting the same grassland (McNaughton, 1985).

A problem with describing geladas as either selective graminivores or bulk-feeders is that overly prescriptive. Geladas alternate between these feeding strategies at hourly, daily, and seasonal temporal scales (Fashing et al., 2014), an ability that distinguishes them from most ungulates. For Jablonski and Leakey (2008), such dietary plasticity is crucial for mitigating the relatively high energetic costs of cortical processing and lactation. For our purposes, it is a It is difficult, however, to differentiate grass-handling behaviors in the fossil record of Theropithecus, which is known for its " $\mathrm{C}_{4}$ signature" (Lee-Thorp et al., 1989; Codron et al., 2005; Cerling et al., 2013; Levin et al., 2015; Robinson et al., 2017). A C 4 signature is an aphorism of stable isotope paleoecologists. It refers to high $\delta^{13} \mathrm{C}$ values that are ultimately predicated on the $\mathrm{C}_{4}$ photosynthetic pathway. The term is convenient but also inscrutable because it fails to distinguish between bulk-feeding grazing and selective graminiviory.

\subsection{Using carbon stable isotopes to discriminate food-handling behavior}


The leaves of $\mathrm{C}_{4}$ grasses are low-quality food (Ehleringer et al., 2002), a view rooted in the high fiber content of $\mathrm{C}_{4}$ species (Clauss et al., 2008b), itself a product of Kranz anatomy and dense bundle sheaths (Heckathorn et al., 1999). Thus, $\mathrm{C}_{4}$ grasses tend to have low proportions of protein and carbohydrate by mass - in short, they are "nutritionally inferior" to $\mathrm{C}_{3}$ grasses (Caswell \& Reed, 1976; Barbehenn et al., 2004). The extent to which $\mathrm{C}_{3}$ and $\mathrm{C}_{4}$ grasses also differ in fracture toughness (resistance to crack propagation; Clauss et al., 2008b) and abrasivity (from siliceous particulate matter; Strömberg et al., 2016) is uncertain and a priority for future research. On balance, selective graminivores are expected to avoid $\mathrm{C}_{4}$ grasses when possible (Yeakel et al., 2014).

Yet, $\mathrm{C}_{4}$ grasses dominate East African grasslands today (exceeding $90 \%$ of the graminoid flora; Osborne et al., 2014), a fact that practically moots any aversion to them. Even so, a degree of $\mathrm{C}_{4}$ aversion (hereafter, selectivity) is detectable using carbon stable isotopes. For example, gazelles (antilopines) are selective graminivores at the level of individual es (selecting the lowestgrowing youngest grass leaves and seeds; Jarman, 1974) and within the grassland community, targeting those species, including dicotyledonous forbs (Bell, 1970) with low fiber contents (Hofmann, 1989). In consequence, the enamel of gazelles is depleted in ${ }^{13} \mathrm{C}$ relative to bulkfeeding grazers, such as zebra (Equus burchelli) and wildebeest (Connochaetes taurinus) in the same (Fig. 1). If we view these $\mathrm{C}_{4}$ signatures as a continuum - from selective graminivory on one end to bulk-feeding grazing on the other-it creates a practical frame of reference, or lens, for interpreting the paleobiology of Theropithecus.

The advantages of are twofold: first, the teeth of gazelles (antilopines), horses (equids), and wildebeests (alcelaphines) are common and readily identified in the fossil record; and second, 
bulk-feeding grazers eat $\mathrm{C}_{3}$ and $\mathrm{C}_{4}$ grasses in proportion to their, functioning as mirrorsat a given time. Referencing Theropithecus to these coeval taxa allows us to control for the confounding effects of $\mathrm{C}_{4}$ grass expansion through time (Patterson et al., 2019) and test classic theory on the relationship between bulk-feeding herbivory and larger body mass (Demment and Van Soest, 1985).

\subsection{Study design}

To detect shifts in the feeding behavior of Theropithecus-including T. brumpti, T. darti, and T. oswaldi (for taxonomic review, see Jablonski and Frost, 2010)—we assembled published carbon stable isotope $\left(\delta^{13} \mathrm{C}\right)$ values spanning the Plio-Pleistocene (Table S1). A deficiency of this data set is the underrepresentation of $\mathrm{C}_{3}$ ecosystems, including those of modern $T$. gelada, which, at the time of writing, was represented by a single published $\delta^{13} \mathrm{C}$ value from the Simien Mountains, Ethiopia (Levin et al., 2008). To fill this empirical void, we focused our own sampling efforts on specimens of Theropithecus inhabiting $\mathrm{C}_{3}$ ecosystems.

For example, we sampled fauna from two North African sites_-Ahl al Oughlam, Morocco dated to $2.5 \mathrm{Ma}\left(33.57^{\circ},-7.51^{\circ}\right.$; Alemseged and Geraads, 1998; Geraads, 2002) and Tighennif, Algeria dated to ca. $1.0 \mathrm{Ma}\left(35.42^{\circ}, 0.33^{\circ}\right.$; Geraads, 2016), or slightly older (Pickford, 2020)_-available in the Muséum National d'Histoire Naturelle, Paris, France. The taxonomy of Theropithecus at Ahl al Oughlam is debated. Some authors view these specimens as early exemplars of T. oswaldi (Pickford, 1993; Jablonski and Frost, 2010), whereas others classify them , T. atlanticus (Alemseged and Geraads, 1998). At Tighennif, our sample includes the largest member of the lineage: T. oswaldi leakeyi (Delson and Hoffstetter, 1993; Delson et al., 2000). Both sites existed in the Mediterranean floral region, a $\mathrm{C}_{3}$ ecosystem (Bocherens et al., 1996). 
This pair of assemblages invites some exploration of the factors that drove T. oswaldi toward extinction. Its large body size predicts a greater commitment to bulk-feeding graminivory, a risky strategy if grasslands diminish in area and/or quality (Lee and Foley, 1993), factors that would increase daily travel costs or impel seasonal migrations (McNaughton, 1985). Yet, the derived hindlimbs of Theropithecus — including a retroflexed femur and tibia (Guthrie, 2011) increase travel costs over greater distances, being better equipped for seated 'shuffling' (Wrangham, 1980). Indeed, the mean daily travel distance of geladas ranges from 0.6 to $3.5 \mathrm{~km}$ depending on the study site, a fraction of that reported for similar-sized baboons (range: 3.6-13.2 $\mathrm{km}$; Moua, 2015), suggesting that any evidence of long-distance travel in the fossil record of Theropithecus is also evidence of ecological and energetics.

To explore whether T. oswaldi leakeyi endured high travel costs relative to other species in the same assemblage, and relative to its congeneric predecessor at Ahl al Oughlam, we turned to strontium isotope ratios. Because the ${ }^{87} \mathrm{Sr} /{ }^{86} \mathrm{Sr}$ ratios of soils enter food webs through leaching by surface waters, variation exists at landscape-level spatial scales, which, in turn, is integrated into animal tissues . Thus, when a population or species travels over greater distances it will express more variable ${ }^{87} \mathrm{Sr} /{ }^{86} \mathrm{Sr}$ ratios (Crowley and Godfrey, 2019). suggest food limitation and high travel costsfor a species then .

In addition, we sampled the tooth enamel of $T$. gelada from two sites, an ecologically-intact Afroalpine grassland in the Guassa Community Conservation Area, Ethiopia $\left(10.25^{\circ}-10.45^{\circ}\right.$, $39.75^{\circ}-39.82^{\circ}$; Fashing et al., 2014), and accessioned in the National Museum of Ethiopia, and from "highlands near Debre Birhan" (Ciochon, 1995), Ethiopia, and housed in the Laboratory for 
Human Evolutionary Studies, University of California, Berkeley. Conditions at the latter site are unknown, but a population exists in the area today, where it subsists partly on $\mathrm{C}_{4}$ grasses and sedges at elevations between 2,735 and 2,847 m a.s.l. (Yazezew et al., 2020). The geladas at Guassa forage at greater elevations (3,200-3,600 $\mathrm{m}$ a.s.1.), which predicts a $\mathrm{C}_{3}$-dominated diet (Tieszen et al., 1979).

Last, we capitalized on the opportunity to compare the fracture toughness of $\mathrm{C}_{3}$ grasses and forbs at Guassa (Venkataraman et al., 2014) with those of $\mathrm{C}_{4}$ grasses and $\mathrm{C}_{3}$ browse plants in Laikipia, Kenya, a $\mathrm{C}_{4}$-dominated woodland savanna, using the same instrumentation and methods. Our intent with this modest data set is twofold; first, it enables us to approximate the properties of plant tissues chewed by; and second, it allows us to test the presumption that $\mathrm{C}_{3}-\mathrm{C}_{4}$ differences in fiber content correspond with differences in fracture toughness, two structural properties of plants that covary nonlinearly (Lucas et al., 2000).

\section{Materials and methods}

\subsection{Sample preparation and analysis}

We sampled tooth enamel with a precision dental drill. In the case of loose bone fragments, we ground the bone with an agate mortar and pestle. The material $(\approx 5 \mathrm{mg})$ was then washed in 2-3\% $\mathrm{NaOCl}$ and soaked in $1 \mathrm{M}$ acetic acid with calcium acetate buffer $(\mathrm{pH}=5.2)$ to remove diagenetic carbonates. The samples were then washed, dried, and weighed $(\approx 1.5 \mathrm{mg})$ for combustion in a 
Micromass Optima dual inlet mass spectrometer, Department of Earth and Planetary Sciences, University of California, Santa Cruz. Isotope ratios for $\mathrm{C}$ and $\mathrm{O}$ are presented as $\delta$ values, where

$\delta^{13} \mathrm{C}=1,000\left[\left(\mathrm{R}_{\text {sample }} / \mathrm{R}_{\text {standard }}\right)-1\right](1)$

$\delta^{18} \mathrm{O}=1,000\left[\left(\mathrm{R}_{\text {sample }} / \mathrm{R}_{\text {standard }}\right)-1\right](2)$

and $\mathrm{R}=$ either ${ }^{13} \mathrm{C} /{ }^{12} \mathrm{C}$ or ${ }^{18} \mathrm{O} /{ }^{16} \mathrm{O}$. Reference standards are Vienna PeeDee belemnite (VPDB) for carbon and standard mean oceanic water (SMOW) for oxygen (reported in VPDB scale in Tables 1 and 2). Units were expressed as parts per thousand (\%). Analytical precision ( $\pm 1 \mathrm{SD})$ based on the NBS 19 standard was $\delta^{13} \mathrm{C}=1.93 \pm 0.05 \%$ o $(\mathrm{n}=8)$, very close to the known value of $1.95 \%$.

In some cases, excess enamel was prepared for strontium analysis. The samples were isolated to carbonate as before $(\mathrm{NaOCl}$ and acetic acid + calcium acetate buffer), dissolved in $2 \mathrm{X}$ Nitric Acid in teflon vials, boiled down at $65^{\circ} \mathrm{C}$, and reconstituted in $\mathrm{HCl}$. Solutions were filtered through plastic columns containing a Sr-phillic resin (Strontium Spec Resin) with MilliQ water as the delivery agent. Strontium isotopic values were obtained using a Neptune Multiple Collector ICP-MS at the W. M. Keck Isotope Laboratory, UCSC. Isotope ratios for Sr are presented as atomic ratios $\left({ }^{87} \mathrm{Sr} /{ }^{86} \mathrm{Sr}\right)$ and are reproducible within 0.0004.

\subsection{Calculations and adjustments}

To detect selective graminivory, we computed the mean $\delta^{13} \mathrm{C}$ values of Theropithecus and coeval antilopines and calculated the differences $(\Delta)$ between them. When making this comparison, greater similarity (lower $\Delta$ values) is interpreted as a tendency toward selective graminivory. To 
detect bulk-feeding, we calculated $\Delta$ between Theropithecus and coeval equids and alcelaphines. In these cases, greater similarity (lower $\Delta$ values) is interpreted as a greater tendency toward bulk-feeding graminivory.

Atmospheric $\mathrm{CO}_{2}$ has become increasingly depleted in ${ }^{13} \mathrm{C}$ since the industrial revolution (the "Suess effect" (Keeling et al., 2017). To account for this effect, and to calibrate the values of modern geladas to pre-industrial conditions $\left(\delta^{13} \mathrm{C}_{1750}\right)$, we adjusted the raw $\delta^{13} \mathrm{C}$ values from near Debre Birhan by $+\%$ (deaths in late 1974 or 1975; Russell Ciochon, pers. comm.) and those from Guassa by $+2.00 \%$ (deaths between 2007 and 2014, or 2011 for present purposes). 1975 (7.3\%; Francey et al., 1999) and 2011 (-8.3\%; Keeling et al., 2010).

\subsection{Measures of fracture toughness}

To broaden the comparison of $\mathrm{C}_{3}$ grasses and forbs published by Venkataraman et al. (2014), we measured the fracture toughness of leaves from $\mathrm{C}_{4}$ grasses and $\mathrm{C}_{3}$ browse at the Mpala Research Centre, Laikipia, Kenya, a semiarid savanna-woodland at ca. $1700 \mathrm{~m}$ a.s. $1\left(0.28^{\circ}, 37.88^{\circ}\right.$; see Young et al., 1995 for detailed habitat descriptions). Fracture toughness was measured on fresh plant material with a portable universal FLS-1 tester (Lucas et al., 2001). A scissors test was used to cut tissue and measure the energy (in joules; J) required to initiate and control crack propagation; fracture toughness $\left(\mathrm{J} / \mathrm{m}^{2}\right)$ was calculated by dividing the area under the forcedisplacement curve by the length of the cut. We focused on $\mathrm{C}_{3}$ dicotyledonous plants (browse species; Table S2) and common $\mathrm{C}_{4}$ grass species (Brachiaria lachnantha, Cynodon dactylon, Pennisetum mezzianum, P. stramineum) in the diets of bulk-feeding grazers, cutting each leaf midway between the base and apex and perpendicular to the direction of venation (Dominy and Lucas, 2004). 


\subsection{Statistical analyses}

T. We used correlation analysis to evaluate the relationship between median age (Ma) and $\Delta$ values, In the case of antilopines, we performed our analysis at the tribe (Antilopini) and genus (Gazella) taxonomic levels. Gazella is preferable as a proxy for selective graminivory, but it suffers from a paucity of unequivocal $\delta^{13} \mathrm{C}$ values (Cerling et al., 2015). We also examined variation in the estimated body masses of Theropithecus - gathered from the literature or estimated per Delson et al. (2000)—as a function of $\Delta$ values.

To compare patterns of landscape use, we calculated standard deviations of ${ }^{87} \mathrm{Sr} /{ }^{86} \mathrm{Sr}$ ratios for each species at Ahl al Oughlam and Tighennif, and we used Levene's Test to compare the magnitude of seawater-normalized variance in specimens of T. atlanticus and T. oswaldi leakeyi. To assess the strength of this latter test, we calculated the effect size per Nakagawa et al. (2015). In the case of $T$. atlanticus, we combined ${ }^{87} \mathrm{Sr} /{ }^{86} \mathrm{Sr}$ ratios from $\mathrm{P} 4$ and $\mathrm{M} 2$ despite developmental differences in crown formation time - in geladas, the M2 mineralizes ca. 18 months later than P4 at 3 years of age (Swindler and Beynon, 1993), and before initial male dispersal around 4.5 years of age (Beehner et al., 2009). Thus, ${ }^{87} \mathrm{Sr} /{ }^{86} \mathrm{Sr}$ ratios from $\mathrm{P} 4$ and M2 are expected to reflect natal landscapes for both sexes.

We used Welch's t-test to compare variation in Suess-corrected carbon isotope values of modern geladas, and ANOVA for comparisons between Ln-transformed data on the fracture toughness of leaves across four functional categories of plants edible to African ungulates. All statistical tests were performed in JMP 15 Pro and $\alpha$ was set at 0.05 . 


\section{Results}

Our results from Ahl al Oughlam and Tighennif are reported in Tables 1 and 2, respectively. In both assemblages, the magnitude of ${ }^{13} \mathrm{C}$-depletion across graminivores, including Theropithecus, speaks to the dominance of $\mathrm{C}_{3}$ grasses in each ecosystem, affirming expectations. In our data set representing T. gelada, we found a comparable range of $\delta^{13} \mathrm{C}$ values after correcting for the Suess effect (Table 3), affirming the dominance of $\mathrm{C}_{3}$ grasses in high-elevation grasslands. However, the $\delta^{13} \mathrm{C}$ values of geladas from Guassa (mean $\delta^{13} \mathrm{C}_{1750} \pm 1 \mathrm{SD}:-11.5 \pm 0.4 \%$ ) differ from those near Debre Birhan (mean $\delta^{13} \mathrm{C}_{1750} \pm 1$ SD: $- \pm \%$; $\mathrm{t}_{3}=-1.2, p<0.0001$ ), indicating the regular exploitation of $\mathrm{C}_{4}$ resources by the latter population (Yazezew et al., 2020).

\subsection{Discriminating between selective graminivory and bulk-feeding graminivory}

To explore temporal trends in selective graminivory, we combined our findings with published values (Table S1) and calculated the mean $\delta^{13} \mathrm{C}$ values of Theropithecus and coeval antilopines before calculating the difference $(\Delta)$ between them. We found that $\Delta$ varied erratically through timeregardless of whether our analysis included all antilopines () or Gazella $(r=0 ., p=0.5, n=7$ assemblages). $\Delta$ values explained little variation in the estimated body mass of Theropithecus (), which suggests that antilopine- or gazelle-like $\delta^{13} \mathrm{C}$ values are a poor measure of selective graminivory.

To explore temporal trends in bulk-feeding graminivory, we calculated the mean $\delta^{13} \mathrm{C}$ values of Theropithecus and coeval alcelaphines and equids and calculated the differences $(\Delta)$ between each pair. In both cases, we found that $\Delta$ values diminished through time, indicating increasing convergence between Theropithecus and alcelaphines (Fig. 2a) and equids (Fig. 2b). In accord with our prediction ( $\mathrm{P} 1)$, variation in these $\Delta$ values explains a significant amount of variation in 
the body mass of Theropithecus (4). Such results demonstrate robust temporal coupling between bulk-feeding graminivory and selection for larger body size.

\subsection{Strontium isotope variation}

To compare landscape use, we measured ${ }^{87} \mathrm{Sr} /{ }^{86} \mathrm{Sr}$ ratios in the assemblages from Ahl al Oughlam (Table 1) and Tighennif (Table 2). At Ahl al Oughlam, the greatest variance was evident among bulk-feeding grazing ungulates, whereas that of T. atlanticus was lower and similar in magnitude to Gazella (Fig. 4a). Tellingly, the variance of Gazella is relatively constant at Ahl al Oughlam and Tighennif, whereas that of Theropithecus differs-indeed, the variance within T. oswaldi leakeyi matches or exceeds that of bulk-feeding grazing ungulates (Fig. 4b), indicating wide-ranging use of the landscape at the time of tooth mineralization. The $\left(F_{1,16}=\right.$ $29.11, p<0.0001)$, a result with a moderately large effect size $(\operatorname{LnCVR}=-0.47$; Cohen's $d$ equivalent $=0.61$.

\subsection{Graminoid fracture toughness}

, we compared variation in the fracture toughness of leaves from different forms of $\mathrm{C}_{3}$ and $\mathrm{C}_{4}$ plants edible to African ungulates (Table S2). Contrary to our prediction (P3), the fracture toughness of leaves from $\mathrm{C}_{3}$ and $\mathrm{C}_{4}$ graminoid plants did not differ, although, collectively, we found that graminoid leaves are tougher than those of forbs or woody browse (Fig. 5).

\section{Discussion}

Our paper reports data in the service of three predictions. First, we found that differences $(\Delta)$ in the mean $\delta^{13} \mathrm{C}$ values of Theropithecus and coeval equids and alcelaphines, narrowed steadily over the course of 3.5 million years. This convergence in carbon isotope values explains a 
significant amount of temporal variation in the body mass of Theropithecus, affirming our prediction (P1) of form-functional synergies between grass-handling behavior and morphology. This finding is especially pronounced for the $T$. oswaldi lineage. Second, we found that variation in the ${ }^{87} \mathrm{Sr} /{ }^{86} \mathrm{Sr}$ ratios of North African Theropithecus differed between 2.5 to $1.0 \mathrm{Ma}$, supporting our prediction (P2) that T. oswaldi leakeyi greater distances during juvenile life. Third, we found little difference in the fracture toughness of $\mathrm{C}_{3}$ and $\mathrm{C}_{4}$ grass blades, contrary to $\mathrm{P} 3$ suggests . By themselves, these disparate data do little more than fill a few empirical voids, but together they shine new light on the paleobiology of Theropithecus.

\subsection{Distinguishing between bulk-feeding and selective graminivory}

Our findings are significant for cutting through the fog of raw $\delta^{13} \mathrm{C}$ values, a blunt instrument that cannot explain variation in body mass (Fig. S) because the photosynthetic pathways of graminoid plants vary in space and time. Our results also refine the typology of 'graminivore,' as we show that grass-handling behavior changed steadily, and further, that a greater reliance on bulk-feeding graminivory explains selection for the increasingly larger size of $T$. oswaldi, which topped out at $128 \mathrm{~kg}$ (Delson et al., 2000). Energetic explanations for this co-varying relationship are multifaceted, including the benefits of lower relative metabolic needs (Jarman, 1974), longer gut passage times (Demment and Van Soest, 1985), and greater fasting endurance (an extension of Cope's Rule; Bhat et al., 2019), all of which are familiar arguments for ungulates. In the case of Theropithecus, however, the absence of gastrointestinal fermentative chambers sets a higher floor and lower (grass) ceiling for occupying a graminivorous niche — in other words, Pleistocene members of Theropithecus faced far narrower constraints than grazing ungulates did. 
, and it is most improbable for Theropithecus (Jablonski and Leakey, 2008), so bulk-feeding graminivory is tenable only when high-quality grass is hyper-abundant. If this resource dwindles, the benefits of large body size can become an evolutionary trap (sensu Schlaepfer et al. 2002). Our strontium isotope results hint at such a trap, with the elevated ${ }^{87} \mathrm{Sr} /{ }^{86} \mathrm{Sr}$ variability of $T$. oswaldi leakeyi pointing to greater, equid-like travel costs relative to baseline-i.e., their predecessors at Ahl al Oughlam, which some authors view as the same species (for a parallel interpretation from Pleistocene Australia, see Price et al. 2017). Of course, our preferred interpretation assumes that the ${ }^{87} \mathrm{Sr} /{ }^{86} \mathrm{Sr}$ ratios of $T$. oswaldi leakeyi are exceptionally variable instead of the alternative (that those of Ahl al Oughlam are exceptionally invariant), which is a weakness of comparing only two fossil assemblages.

Another explanation for our findings concerns sex differences in dispersal behavior. It is plausible that four outlier values of T. oswaldi leakeyi are those of males that emigrated from natal groups farther from the coast. But this argument is weakened by the corollary premise of sex-biased sampling — an overrepresentation of females, the philopatric sex of cercopithecid monkeys - in our sample from Ahl al Oughlam. Such bias is unlikely given that the probability of sampling 10 females in an assemblage with a 1:2 female to male sex ratio (Alemseged and Geraads, 1998$)$ is vanishingly small $(0.0017 \%)$. Assuming a comparable number of males in both collections of tooth fragments is parsimonious, and it argues for both sexes of $T$. oswaldi leakeyi enduring greater travel costs.

Our findings invite discussion on the survival and isolation of $T$. gelada in the highlands of Ethiopia. Behavioral observations of geladas describe selective graminivory as a prevailing foraging strategy (Fashing et al., 2014; Souron, 2018), a sharp reversal to the long-term trend 
reported here but corroborating those who argue that the size and dietary behavior of $T$. gelada are reflective of stem character traits (Jablonski, 1993). Indeed, we found that the $\delta^{13} \mathrm{C}_{1750}$ values of some geladas (those near Debre Birhan) resemble those of the earliest members of the genus at Kanapoi, Kenya, ca. 4.2 Ma (Frost et al., 2020; Manthi et al., 2020). Still, it is uncertain whether the primitive traits of geladas were retained in a 'refuge' habitat (Tappen, 1960) or secondarily evolved after colonizing a resource-limited 'ecological island' (Dunbar, 1998). In the latter case, our results would suggest that colonizing individuals experienced little change to the toughness of their diet even if the overall quality improved due to the (presumed) lower fiber content of $\mathrm{C}_{3}$ graminoid species (Fig. 5). Such questions are priorities for future research.

\section{2}

In the footsteps of Lee and Foley (1993) and in the spirit of Greene (2017), it is useful to fold our farrago of findings into a scenario that accounts for the rise and collapse of the genus. It begins by calling attention to 'grazing lawns', a distinct type of short-statured grassland in Africa that is associated with intense grazing (McNaughton, 1984). Grazing ungulates are attracted to these lawns because has a low proportion of stem tissue, which encourages repeat grazing and suppresses tall-grass growth forms that would otherwise outcompete lawn species for light (Hempson et al., 2015). As water concentrates ungulates, grazing lawns tend to form around lake and river margins, where they provide an exceptionally nutritious and stable food resource for papionin primates, including geladas (Dunbar, 1993; Eriksen, 2017).

In light of our carbon isotope results, we envision the origins of Theropithecus in a waterside habitat and premised on a diet of forbs and graminoid tissues, a form of selective graminivory similar to that of geladas today (Souron, 2018). By two million years ago, shifted to obligate 
bulk-feeding graminivory, a behavior that only increased in magnitude through time. It is probably associated with grazing lawns for two reasons: first, allometric increases in foraging time, coupled with daylight constraints, would have imposed limits on larger-bodied species, forcing them to forage almost exclusively on the highest-quality, highest-density graminoid tissues available (Fig. 6); and second, the fossil record points to strong associations between $T$ and paleolake margins and river courses (Geraads et al., 1986; Reed, 2008; Quinn, 2015; Curran and Halie-Selassie, 2016; Bobe et al., 2020). We agree with Dunbar (1993) that lake- or rivermediated grazing lawns are essentially the only habitat that could support a monkey engaged in high-throughput bulk-feeding graminivory.

The problems of being fettered to this niche are fourfold. First, the bulk-feeding graminivory of T. oswaldi would represent an excessive proportion of its daily activity budget - exceeding $95 \%$ in the most extreme case (Fig. 6). Second, perpetual mastication would come at the expense of essential social behaviors, such as allogrooming (Iwamoto and Dunbar, 1983; Dunbar, 1992). Third, reduced grooming is expected to destabilize group cohesion (Dunbar, 1993) and increase predation risk (Lin et al., 2020), including at the hands of early Homo (Shipman et al., 1981). Last, classic life history theory predicts a tension between development and reproduction, with bulk-feeding favoring slower growth rates, larger bodies, and delayed reproduction (Lu et al., 2016), whereas a greater risk of predation is expected to favor earlier reproductive maturity and smaller adult body sizes. These conflicting pressures are predicted to result in demographic fragility and greater susceptibility to extinction (Lee and Foley, 1993).

Collapse was perhaps inevitable as lake basin hydrology became increasingly variable (Potts, 1998) in response to greater climatic variability between 1.2 and $0.8 \mathrm{Ma}$ (deMenocal, 2004). 
Rapid fluctuations in lake hydrology would have affected the total area and productivity of grazing lawns (Hempson et al., 2015), forcing $T$ to travel greater distances over the landscapebut not migration (Jablonski and Leakey, 2008)—in search of food, further exacerbating constraints on an activity budget with little margin for non-feeding behaviors (Fig. 6). Such a dire scenario of increasing food and travel stress predicts greater strontium isotope variability among the largest, end-Pleistocene members of the genus, which is precisely what we report here.

\section{Conclusions}

We conclude that the evolution of Theropithecus during the Plio-Pleistocene (4.2-0.7 Ma) is defined by a progressive reliance on high-throughput bulk-feeding graminivory. We found that variation in bulk-feeding behavior explains a significant amount of variation in body mass, and we describe this behavior and corresponding large size, both of which peaked in the Pleistocene, as evolutionary traps. To support this characterization, we report evidence of temporal increases in strontium isotope variability among North African theropiths, a result that indicates greater ranging costs in response to diminishing food resources, a probable factor in the extinction of $T$. oswaldi, the largest monkey that ever lived.

\section{Declaration of competing interests}

The authors declare that they have no known competing financial interests or personal relationships that could have appeared to influence the work reported in this paper.

\section{Acknowledgements}


We are grateful for the practical assistance of M. Basasen, T. Blackburn, J. W. Chipman, B. E. Crowley, T. Getachew, A. Girmaye, D. Goujet, G. L. Moritz, B. Muluyee, C. Sagne, G. Sineshaw, B. Tessema, S. Tessema, D. Tollstrup, P. V. Wheatley, T. D. White, T. Wudimagegn, T. P. Young, and field assistants of the Guassa Gelada Research Project. Permission to collect and export bone samples from Guassa was granted by the Ethiopian Wildlife Conservation Authority, Authority for Research and Conservation of Cultural Heritage, Amhara Regional Government, and Mehal Meda Woreda. Funding was received from the David and Lucile Packard Foundation (Fellowship in Science and Engineering no. 2007-31754 to N.J.D.), an OTSSTRI Andrew W. Mellon Research Exploration Award in Tropical Biology (to N.J.D.), and three National Science Foundation Graduate Research Fellowships (to L.D.F., V.V.V., and J.D.Y.).

\section{Data availability}

\section{References}

Alemseged, Z., \& Geraads, D. (1998). Theropithecus atlanticus (Thomas, 1884) (Primates: Cercopithecidae) from the Late Pliocene of Ahl al Oughlam, Casablanca, Morocco. Journal of Human Evolution, 34, 609-621.

doi:10.1006/jhev.1998.9999

Barbehenn, R. V., Chen, Z., Karowe, D. N., \& Spickard, A. (2004). C 3 grasses have higher nutritional quality than $\mathrm{C}_{4}$ grasses under ambient and elevated atmospheric CO2. Global Change Biology, 10, 1565-1575.

doi:10.1111/j.1365-2486.2004.00833.x

Bataille, C.P., Crowley, B.E., Wooler, M.J., \& Bowen, G.J. (2020). Advances in global bioavailable strontium isoscapes. Palaeogeography, Palaeoclimatology, Palaeoecology, 555, 109849. doi: 10.1016/j.palaeo.2020.109849 
Beehner, J. C., Gesquiere, L., Seyfarth, R. M., Cheney, D. L., Alberts, S. C., \& Altmann, J. (2009). Testosterone related to age and life-history stages in male baboons and geladas. Hormones and Behavior, 56, 472-480. doi:10.1016/j.yhbeh.2009.08.005

Bell, R. H. V. (1970). The use of the herb layer by grazing ungulates in the Serengeti. In A. Watson (Ed.), Animal populations in relation to their food resources (pp. 111-124). Oxford: Blackwell Science Publishing.

Bhat, U., Kempes, C. P., \& Yeakel, J. D. (2020). Scaling the risk landscape drives optimal life-history strategies and the evolution of grazing. Proceedings of the National Academy of Sciences USA, 117, 1580-1586. doi:10.1073/pnas.1907998117

Bobe, R., Manthi, F.K., Ward, C.V., Plavcan, J.M., \& Carvalho, S. (2020). The ecology of Australopithecus anamensis in the early Pliocene of Kanapoi, Kenya. Journal of Human Evolution, 140, 102717. doi:10.1016/j.jhevol.2019.102717

Bocherens, H., Koch, P. L., Mariotti, A., Geraads, D., \& Jaeger, J. J. (1996). Isotopic biogeochemistry $\left(\delta^{13} C, \delta^{18} \mathrm{O}\right)$ of mammalian enamel from African Pleistocene hominid sites. Palaios, 11, 306-318. doi:10.2307/3515241

Caswell, H., \& Reed, F. C. (1976). Plant-herbivore interactions: the indigestibility of $\mathrm{C}_{4}$ bundle sheath cells by grasshoppers. Oecologia, 26, 151-156. doi:10.1007/BF00582893

Curran, S.C., \& Haile-Selassie, Y. (2016). Paleoecological reconstruction of hominin-bearing middle Pliocene localities at Woranso-Mille, Ethiopia. Journal of Human Evolution, 96, 97-112. doi: 10.1016/j.jhevol.2016.04.002

Cerling, T. E., Chritz, K. L., Jablonski, N. G., Leakey, M. G., \& Manthi, F. K. (2013). Diet of Theropithecus from 4 to $1 \mathrm{Ma}$ in Kenya. Proceedings of the National Academy of Sciences USA, 110, 10507-10512.

doi:10.1073/pnas.1222571110 
Cerling, T. E., Andanje, S. A., Blumenthal, S. A., Brown, F. H., Chritz, K. L., Harris, J. M., ... \& Leakey, M. G. (2015). Dietary changes of large herbivores in the Turkana Basin, Kenya from 4 to 1 Ma. Proceedings of the National Academy of Sciences USA, 112, 11467-11472. doi:10.1073/pnas.1513075112

Ciochon, R. L. (1995) A remarkable lineage. Review of Theropithecus: the rise and fall of a primate genus. Edited by Nina Jablonski (1993) Cambridge: University of Cambridge Press. 550 pp. ISBN 0-521-41105X. \$195.00. Evolutionary Anthropology, 4, 32-36. doi:10.1002/evan.1360040107

Clauss, M., Streich, W. J., Nunn, C. L., Ortmann, S., Hohmann, G., Schwarm, A., \& Hummel, J. (2008a). The influence of natural diet composition, food intake level, and body size on ingesta passage in primates. Comparative Biochemistry and Physiology Part A: Molecular and Integrative Physiology, 150, 274-281.

doi:10.1016/j.cbpa.2008.03.012

Clauss, M., Kaiser, T., \& Hummel, J. (2008b). The morphophysiological adaptations of browsing and grazing mammals. In I. J. Gordon \& H. H. T. Prins (Eds.), The Ecology of Browsing and Grazing (pp. 47-88). Berlin: Springer-Verlag.

Clauss, M., Nunn, C., Fritz, J., \& Hummel, J. (2009). Evidence for a tradeoff between retention time and chewing efficiency in large mammalian herbivores. Comparative Biochemistry and Physiology Part A: Molecular and Integrative Physiology, 154, 376-382. doi:10.1016/j.cbpa.2009.07.016

Codron, D., Luyt, J., Lee-Thorp, J. A., Sponheimer, M., de Ruiter, D., \& Codron, J. (2005). Utilization of savannabased resources by Plio-Pleistocene baboons. South African Journal of Science, 101, 245-248. doi:10.5167/uzh25352

Crowley, B. E., \& Godfrey, L. R. (2019). Strontium isotopes support small home ranges for extinct lemurs. Frontiers in Ecology and Evolution, 7, 490. doi:10.3389/fevo.2019.00490 
Delson, E., \& Hoffstetter, R. (1993). Theropithecus from Ternifine, Algeria. In N. G. Jablonski (Ed.), Theropithecus: the rise and fall of a primate genus (pp. 191-208). Cambridge: Cambridge University Press. doi:10.1017/CBO9780511565540.007

Delson, E., Terranova, C. J., Jungers, W. L., Sargis, E. J., Jablonski, N. G., \& Dechow, P. C. (2000). Body mass in Cercopithecdiae (Primates, Mammalia): estimation and scaling in extinct and extant taxa. American Museum of Natural History, Anthropology Papers, 83, 1-159.

deMenocal, P. B. (2004). African climate change and faunal evolution during the Pliocene-Pleistocene. Earth and Planetary Science Letters, 220, 3-24. doi:10.1016/S0012-821X(04)00003-2

Demment, M. W., \& Van Soest, P. J. (1985). A nutritional explanation for body-size patterns of ruminant and nonruminant herbivores. American Naturalist, 125, 641-672. doi:10.1086/284369

Dominy, N. J., \& Lucas, P. W. (2004). Significance of color, calories, and climate to the visual ecology of catarrhines. American Journal of Primatology, 62, 189-207. doi:10.1002/ajp.20015

Du, A., Robinson, J. R., Rowan, J., Lazagabaster, I. A., \& Behrensmeyer, A. K. (2019). Stable carbon isotopes from paleosol carbonate and herbivore enamel document differing paleovegetation signals in the eastern African PlioPleistocene. Review of Palaeobotany and Palynology, 261, 41-52. doi: 10.1016/j.revpalbo.2018.11.003

Dunbar, R. I. M. (1977). Feeding ecology of gelada baboons: a preliminary report. In T. H. Clutton-Brock (Ed.), Primate Ecology: Studies of feeding behavior and ranging behaviour in lemurs, monkeys and apes (pp. 251-273). London: Academic Press.

Dunbar, R. I. M. (1983). Theropithecines and hominids: contrasting solutions to the same ecological problem. Journal of Human Evolution, 12, 647-658. doi:10.1016/S0047-2484(83)80004-9 
Dunbar, R.I.M. (1992). Time: a hidden constraint on the behavioural ecology of baboons. Behavioral Ecology and Sociobiology, 31, 35-49. doi: 10.1007/BF00167814

Dunbar, R. I. M. (1993). Socioecology of the extinct theropiths: a modeling approach. In N. G. Jablonski (Ed.), Theropithecus: the Rise and Fall of a Primate Genus (pp. 465-486). Cambridge: Cambridge University Press. doi: 10.1017/CBO9780511565540.019

Dunbar, R. I. M. (1998). Impact of global warming on the distribution and survival of the gelada baboon: a modelling approach. Global Change Biology, 4, 293-304. doi:10.1046/j.1365-2486.1998.00156.x

Dunbar, R. I. M., \& Bose, U. (1991). Adaptation to grass-eating in gelada baboons. Primates, 32, 1-7. doi:10.1007/BF02381596

Ehleringer, J.R., Cerling, T.E. \& Dearing, M.D. 2002 Atmospheric CO2 as a global change driver influencing plantanimal interactions. Integrative and Comparative Biology, 42, 424-430. doi:10.1093/icb/42.3.424

Eriksen, G.A. (2017). Foraging strategies of wild gelada monkeys (Theropithecus gelada) in an Afroalpine grassland at Guassa, Ethiopia. MSc thesis. University of Oslo, Oslo.

Fashing, P. J., Nguyen, N., Venkataraman, V. V., \& Kerby, J. T. (2014). Gelada feeding ecology in an intact ecosystem at Guassa, Ethiopia: variability over time and implications for theropith and hominin dietary evolution. American Journal of Physical Anthropology, 155, 1-16. doi:10.1002/ajpa.22559

Francey, R. J., Allison, C. E., Etheridge, D. M., Trudinger, C. M., Enting, I. G., Leuenberger, M.,...\& Steele, L. P. (1999). A 1000-year high precision $\delta^{13} \mathrm{C}$ in atmospheric $\mathrm{CO}_{2}$. Tellus, 51, 170-193. doi:10.1034/j.1600-

0889.1999.t01-1-00005.x 
Frost, G. S., Walton, G. E., Swann, J. R., Psichas, A., Costabile, A., Johnson, L. P., ... \& Barraclough, T. G. (2014). Impacts of plant-based foods in ancestral hominin diets on the metabolism and function of gut microbiota in vitro. mBio, 5, e00853-14. doi:10.1128/mBio.00853-14

Frost, S. R., Ward, C. V., Manthi, F. K., \& Plavcan, J. M. (2020). Cercopithecid fossils from Kanapoi, West Turkana, Kenya (2007-2015). Journal of Human Evolution, 140, 102642. doi:10.1016/j.jhevol.2019.102642

Geraads, D. (2002). Plio-Pleistocene mammalian biostratigraphy of Atlantic Morocco. Quaternaire, 13, 43-53. doi:10.3406/quate.2002.1702

Geraads, D. (2016). Pleistocene Carnivora (Mammalia) from Tighennif (Ternifine), Algeria. Geobios, 49, 445-458. doi:10.1016/j.geobios.2016.09.001

Geraads, D., \& Bonis de, L. (2019). First record of Theropithecus (Cercopithecidae) from the Republic of Djibouti. Journal of Human Evolution, 138, 102686. doi:10.1016/j.jhevol.2019.102686

Geraads, D., Hublin, J.J., Jaeger, J.J., Tong, H., Sen, S., \& Toubeau, P. (1986). The Pleistocene hominid site of Ternifine, Algeria: New results on the environment, age, and human industries. Quaternary Research, 25, 380-386. doi:10.1016/0033-5894(86)90008-6

Gibert, J., Ribot, F., Gibert, L., Leakey, M., \& Arribas, A. (1995). Presence of the cercopithecid genus Theropithecus in Cueva Victoria (Murcia, Spain). Journal of Human Evolution, 28, 487-493. doi:10.1006/jhev.1995.1036

Greene, H. W. (2017). Evolutionary scenarios and primate natural history. American Naturalist, 190, S69-S86. doi:10.1086/692830 
Gupta, V. L., \& Sahani, A. (1981). Theropithecus delsoni, a new cercopithecine species from the Upper Siwaliks of India. Bulletin of the Indian Geological Association, 14, 69-71.

Guthrie, E. H. (2011). Functional morphology of the postcranium of Theropithecus brumpti (Primates:

Cercopithecidae). PhD thesis, University of Oregon, Eugene.

Heckathorn, S. A., McNaughton, S. J., \& Coleman, J. S. (1999). C4 plants and herbivory. In R. F. Sage \& R. K. Monson (Eds.), $C_{4}$ Plant Biology (pp. 285-312). San Diego: Academic Press.

Hamilton, M.I., Fernandez, D. P., \& Nelson, S. V. (2021). Using strontium isotopes to determine philopatry and dispersal in primates: a case study from Kibale National Park. Royal Society Open Science, 8, 200760.

Hempson, G. P., Archibald, S., Bond, W. J., Ellis, R. P., Grant, C. C., Kruger, F. J., ... \& Smit, I. P. (2015). Ecology of grazing lawns in Africa. Biological Reviews, 90, 979-994. doi:10.1111/brv.12145

Hess, J., Bender, M. L., Schilling, J. G. (1986). Evolution of the ratio of strontium-87 to strontium-86 in seawater from Cretaceous to present. Science, 231, 979-984. doi:10.1126/science.231.4741.979

Hill, W. C. O. (1970). Primates, comparative anatomy and taxonomy. Vol. VIII. Cynopithecinae, Papio, Mandrillus, Theropithecus. Edinburgh: Edinburgh University Press.

Hofmann, R. R. (1989). Evolutionary steps of ecophysiological adaptation and diversification of ruminants: a comparative view of their digestive system. Oecologia, 78, 443-457. doi:10.1163/156853974X00345

Hunter, C. P. (2001). Ecological determinants of gelada ranging patterns (Theropithecus gelada). PhD thesis. University of Liverpool, UK. 
Iwamoto, T. (1993). Food digestion and energetic conditions in Theropithecus gelada. In N. G. Jablonski (Ed.), Theropithecus: the rise and fall of a primate genus (pp. 453-463). Cambridge: Cambridge University Press. doi:10.1017/CBO9780511565540.018

Iwamoto, T., \& Dunbar, R. I. M. (1983). Thermoregulation, habitat quality and the behavioural ecology of gelada baboons. Journal of Animal Ecology, 52, 357-366. doi: 10.2307/4559

Jablonski, N. G. (1993). The phylogeny of Theropithecus. In N. G. Jablonski (Ed.), Theropithecus: the rise and fall of a primate genus (pp. 209-224). Cambridge: Cambridge University Press. doi: 10.1017/CBO9780511565540.008

Jablonski, N. G. (1994). Convergent evolution in the dentitions of grazing macropodine marsupials and the grasseating cercopithecine primate Theropithecus gelada. Journal of the Royal Society of Western Australia, 77, 37-43.

Jablonski, N. G., \& Frost, S. R. (2010). Cercopithecoidea. In L. Werdelin \& W. J. Sanders (Eds.), Cenozoic Mammals of Africa (pp. 393-428). Berkeley, California: University of California Press.

Jablonski, N. G., \& Leakey, M. G. (2008). The importance of the cercopithecoidea from the Koobi Fora formation in the context of primate and mammalian evolution. In N. G. Jablonski \& M. G. Leakey (Eds.), Koobi Fora Research Project: The Fossil Monkeys (Vol. 6, pp. 397-416). San Francisco: California Academy of Sciences.

Jablonski, N. G., Leakey, M. G., Kiarie, C., \& Antón, M. (2002). A new partial skeleton of Theropithecus brumpti (Primates: Cercopithecidae) from Lomekwi, West Turkana, Kenya. Journal of Human Evolution, 43, 887-923. doi:10.1006/jhev.2002.0607

Janis, C. (1976). The evolutionary strategy of the equidae and the origins of rumen and cecal digestion. Evolution, 30, 757-774. doi:10.2307/2407816 
Jarman, P. J. (1974). The social organization of antelope in relation to their ecology Behaviour, 48, $215-267$. doi:10.1163/156853974X00345

Jarvey, J. C., Low, B. S., Pappano, D. J., Bergman, T. J., \& Beehner, J. C. (2018). Graminivory and fallback foods: annual diet profile of geladas (Theropithecus gelada) living in the Simien Mountains National Park, Ethiopia. International Journal of Primatology, 39, 105-126. doi:10.1007/s10764-018-0018-X

Jolly, C. J. (1972). The classification and natural history of Theropithecus (Simopithecus) (Andrews, 1916), baboons of the African Plio-Pleistocene. Bulletin British Museum (Natural History). Geology, 22, 1-122.

Keeling, R. F., Graven, H. D., Welp, L. R., Resplandy, L., Bi, J., Piper, S. C., ... \& Meijer, H. A. (2017). Atmospheric evidence for a global secular increase in carbon isotopic discrimination of land photosynthesis. Proceedings of the National Academy of Sciences USA, 114, 10361-10366. doi:10.1073/pnas.1619240114

Lee, P. C., \& Foley, R. A. (1993). Ecological energetics and extinction of giant gelada baboons. In N. G. Jablonski (Ed.), Theropithecus: the rise and fall of a primate genus (pp. 487-498). Cambridge: Cambridge University Press. doi: 10.1017/CBO9780511565540.020

Lee-Thorp, J. A., van der Merwe, N. J., \& Brain, C. K. (1989). Isotopic evidence for dietary differences between two extinct baboon species from Swartkrans. Journal of Human Evolution, 18, 183-190. doi:10.1016/00472484(89)90048-1

Levin NE, Simpson SW, Quade J, Cerling TE, Frost SR. 2008 Herbivore enamel carbon isotopic composition and the environmental context of Ardipithecus at Gona, Ethiopia. In The geology of early humans in the horn of Africa: Geological Society of America special paper (eds J Quade, JG Wynn), pp. 215-234. Boulder: Geological Society of America. 
Levin, N. E., Haile-Selassie, Y., Frost, S. R., \& Saylor, B. Z. (2015). Dietary change among hominins and cercopithecids in Ethiopia during the early Pliocene. Proceedings of the National Academy of Sciences USA, 112, 12304-12309. doi:10.1073/pnas.1424982112

Lin, B., Foxfoot, I.R., Miller, C.M., Venkataraman, V.V., Kerby, J.T., Bechtold, ... \& Fashing PJ. (2020). Leopard predation on gelada monkeys at Guassa, Ethiopia. American Journal of Primatology, 82, e23098.

doi:10.1002/ajp.23098

Lucas, P. W., Turner, I. M., Dominy, N. J., \& Yamashita, N. (2000). Mechanical defences to herbivory. Annals of Botany, 86, 913-920. doi:10.1006/anbo.2000.1261

Lucas, P. W., Beta, T., Darvell, B.W., Dominy, N.J., Essackjee, H.C., Lee, P.K.D., ...Yuen, T.D.B. (2001). Field kit to characterize physical, chemical and spatial aspects of potential primate foods. Folia Primatologica, 72, 11-25. doi:10.1159/000049914

Lu, A., Bergman, T. J., McCann, C., Stinespring-Harris, A., \& Beehner, J. C. (2016). Growth trajectories in wild geladas (Theropithecus gelada). American Journal of Primatology, 78, 707-719. doi:10.1002/ajp.22535

Manthi, F. K., Cerling, T. E., Chritz, K. L., \& Blumenthal, S. A. (2020). Diets of mammalian fossil fauna from Kanapoi, northwestern Kenya. Journal of Human Evolution, 140, 102338. doi:10.1016/j.jhevol.2017.05.005

Mau, M., Südekum, K. H., Johann, A., Sliwa, A., \& Kaiser, T. M. (2009a). Saliva of the graminivorous Theropithecus gelada lacks proline-rich proteins and tannin-binding capacity. American Journal of Primatology, 71, 663-669. doi:10.1002/ajp.20701

Mau, M., Kaiser, T. M., \& Südekum, K. H. (2009b). Evidence for the presence of carbonic anhydrase 29-kDa isoenzyme in salivary secretions of three ruminating species and the gelada baboon. Archives of Oral Biology, 54, 354-360. doi:10.1016/j.archoralbio.2008.12.004 
Mau, M., Johann, A., Sliwa, A., Hummel, J., \& Südekum, K. H. (2011). Morphological and physiological aspects of digestive processes in the graminivorous primate Theropithecus gelada - a preliminary study. American Journal of Primatology, 73, 449-457. doi:10.1002/ajp.20921

McNaughton, S. J. (1984). Grazing lawns: animals in herds, plant form, and coevolution. The American Naturalist, 124, 863-886. doi:10.1086/284321

McNaughton, S. J. (1985). Ecology of a grazing ecosystem: the Serengeti. Ecological Monographs, 55, 259-294. doi:10.2307/1942578

Moua, C. (2015). Long-term ranging patterns of wild gelada monkeys (Theropithecus gelada) on intact afro-alpine grasslands at Guassa, Ethiopia. MSc thesis, University of California, Fullerton.

Nakagawa, T., Poulin, R., Mengersen, K., Reinhold, K., Engqvist, L., Lagisz, M., \& Senior, A.M. (2015). Metaanalysis of variation: ecological and evolutionary applications and beyond. Methods in Ecology and Evolution, 6, 143-152. doi:10.1111/2041-210X.12309

Osborne, C. P., Salomaa, A., Kluyver, T. A., Visser, V., Kellogg, E. A., Morrone, O., ... \& Simpson, D. A. (2014). A global database of $\mathrm{C}_{4}$ photosynthesis in grasses. New Phytologist, 204, 441-446. doi:10.1111/nph.12942

Patterson, D. B., Braun, D. R., Allen, K., Barr, A. W., Behrensmeyer, A. K., Biernat, M., . . \& Bobe, R. (2019). Comparative isotopic evidence from East Turkana supports a dietary shift within the genus Homo. Nature Ecology and Evolution, 3, 1048-1056. doi:10.1038/s41559-019-0916-0 
Pickford, M. (1993). Climatic change, biogeography, and Theropithecus. In N. G. Jablonski (Ed.), Theropithecus: the Rise and Fall of a Primate Genus (pp. 227-243). Cambridge: Cambridge University Press. doi:

10.1017/CBO9780511565540.009

Pickford, M. (2020). The fossil Suidae (Mammalia, Artiodactyla) from Ternifine (Tighenif) Algeria. Münchner Geowissenschaftliche Abhandlungen, 50, 1-67.

Potts, R. (1998). Environmental hypothesis of hominin evolution. Yearbook of Physical Anthropology, 41, 93-136. doi:10.1002/(SICI)1096-8644(1998)107:27+<93::AID-AJPA5>3.0.CO;2-X

Price, G. J., Ferguson, K. J., Webb, G. E., Feng, Y-x., Higgins, P., Nguyen, A. D.,... Louys., J. (2017). Seasonal migration of marsupial megafauna in Pleistocene Sahul (Australia - New Guinea). Proceedings of the Royal Society $B, 284,20170785$. doi:10.1098/rspb.2017.0785

Quinn, R.L. (2015). Influence of Plio-Pleistocene basin hydrology on the Turkana hominin enamel carbonate $\delta^{18} \mathrm{O}$ values. Journal of Human Evolution, 86, 13-31. doi: 10.1016/j.jhevol.2015.06.004

Reed, K. (2008). Paleoecological patterns at the Hadar hominin site, Afar regional state, Ethiopia. Journal of Human Evolution, 54, 743-768. doi: 10.1016/j.jhevol.2007.08.013

Robinson, J. R., Rowan, J., Campisano, C. J., Wynn, J. G., \& Reed, K. E. (2017). Late Pliocene environmental change during the transition from Australopithecus to Homo. Nature Ecology and Evolution, 1, 0159. doi:10.1038/s41559-017-0159

Schlaepfer, M. A., Runge, M. C., \& Sherman, P. W. (2002). Ecological and evolutionary traps. Trends in Ecology \& Evolution, 17, 474-480. doi:10.1016/S0169-5347(02)02580-6 
Shipman, P., Bosler, W., \& Davis, K. L. (1981). Butchering of giant geladas at an Acheulian site. Current Anthropology, 22, 257-268. doi:10.1086/202663

Souron, A. (2018). Morphology, diet, and stable carbon isotopes: on the diet of Theropithecus and some limits of uniformitarianism in paleoecology. American Journal of Physical Anthropology, 166, 261-267.

doi:10.1002/ajpa.23414

Strömberg, C. A. E., Di Stilio, V. S., \& Song, Z. (2016). Functions of phytoliths in vascular plants: an evolutionary perspective. Functional Ecology, 30, 1286-1297. doi:10.1111/1365-2435.12692

Swindler, D. R., \& Beynon, A. D. (1993). The development and microstructure of the dentition of Theropithecus. In N. G. Jablonski (Ed.), Theropithecus: the Rise and Fall of a Primate Genus (pp. 351-381). New York: Cambridge University Press. doi:10.1017/CBO9780511565540.014

Tappen, N. C. (1960). Problems of distribution and adaptation of the African monkeys. Current Anthropology, 1, 91-120. doi:10.1086/200088

Tieszen, L. L., Senyimba, M. M., Imbamba, S. K., \& Troughton, J. H. (1979). The distribution of $\mathrm{C}_{3}$ and $\mathrm{C}_{4}$ grasses and carbon isotope discrimination along an altitudinal and moisture gradient in Kenya. Oecologia, 37, $337-350$. doi:10.1007/BF00347910

Trosvik, P., de Muinck, E. J., Rueness, E. K., Fashing, P. J., Beierschmitt, E. C., Callingham, K. R., . . Nguyen, N. (2018). Multilevel social structure and diet shape the gut microbiota of the gelada monkey, the only grazing primate. Microbiome, 6, 84. doi:10.1186/s40168-018-0468-6

Venkataraman, V. V., Glowacka, H., Fritz, J., Clauss, M., Seyoum, C., Nguyen, N., \& Fashing, P. J. (2014). Effects of dietary fracture toughness and dental wear on chewing efficiency in geladas (Theropithecus gelada). American Journal of Physical Anthropology, 155, 17-32. doi:10.1002/ajpa.22571Wrangham, R. W. (1980). Bipedal 
locomotion as a feeding adaptation in gelada baboons, and its implications for hominid evolution. Journal of Human Evolution, 9, 329-331. doi:10.1016/0047-2484(80)90059-7

Yazezew D., Bekele A., \& Ibrahim, H. (2020). Activity budget and feeding ecology of geladas (Theropithecus gelada obscurus) around Abogedam Church West of Debre Berhan Town, Ethiopia. Scientific World Journal, 2020, 9829834. doi:10.1155/2020/9829834

Yeakel, J. D., Dominy, N. J., Koch, P. L., \& Mangel, M. (2014). Functional morphology, stable isotopes, and human evolution: A model of consilience. Evolution, 68, 190-203. doi:10.1111/evo.12240

Young, T. P., Patridge, N., \& Macrae, A. (1995). Long-term glades in acacia bushland and their edge effects in Laikipia, Kenya. Ecological Applications, 5, 97-108. doi:10.2307/1942055

\section{$\underline{\text { Main text tables }}$}

Table 1 Carbon and oxygen stable isotope values, and strontium isotope ratios, of fauna analyzed from Ahl al Oughlam, Morocco, dated to ca. 2.5 Ma. Specimens are stored provisionally in the Muséum National d'Histoire Naturelle, Paris, France; uncatalogued specimens are designated "UC". Taxonomy follows Alemseged and Geraads (1998).

\begin{tabular}{|l|l|l|l|l|}
\hline Accession Number & Taxon & $\delta^{13} \mathrm{C}$ & $\delta^{18} \mathrm{O}$ & ${ }^{87} \mathrm{Sr} /{ }^{86} \mathrm{Sr}$ \\
\hline UC & Alcelaphini gen. sp. & -8.9 & -3.3 & \\
\hline UC & Alcelaphini gen. sp. & -8.9 & -4.3 & \\
\hline UC & Gazella sp. & -11.5 & -2.1 & 0.709044 \\
\hline UC & Gazella sp. & -12.2 & -4.4 & 0.709082 \\
\hline
\end{tabular}




\begin{tabular}{|c|c|c|c|c|}
\hline $\mathrm{UC}$ & Gazella sp. & -11.9 & -3.6 & 0.709089 \\
\hline UC & Hiparion & -12.0 & -3.9 & 0.709333 \\
\hline UC & Hiparion & -11.5 & -2.1 & 0.709154 \\
\hline \multirow[t]{2}{*}{$\mathrm{AaO}-3544$} & Hiparion & -11.5 & -2.7 & 0.709956 \\
\hline & Average & $-11.7(0.3)$ & $-2.9(0.9)$ & $\begin{array}{l}0.709481 \\
(0.000421)\end{array}$ \\
\hline UC & Kolpochoerus & -11.5 & -2.4 & \\
\hline $\mathrm{UC}$ & Theropithecus atlanticus & -11.0 & -1.4 & 0.709010 \\
\hline $\mathrm{AaO}-45 \mathrm{e}$ & Theropithecus atlanticus & -13.1 & -2.7 & 0.708902 \\
\hline $\mathrm{AaO}-51$ & Theropithecus atlanticus & -13.4 & -2.2 & 0.708931 \\
\hline $\mathrm{AaO}-452$ & Theropithecus atlanticus & -13.4 & -2.5 & 0.708962 \\
\hline $\mathrm{AaO}-662$ & Theropithecus atlanticus & -12.9 & -0.3 & 0.709227 \\
\hline $\mathrm{AaO}-947$ & Theropithecus atlanticus & -11.3 & -1.2 & 0.709126 \\
\hline $\mathrm{AaO}-3144$ & Theropithecus atlanticus & -12.1 & -1.8 & 0.709068 \\
\hline $\mathrm{AaO}-4125$ & Theropithecus atlanticus & -11.8 & -2.0 & 0.709116 \\
\hline $\mathrm{AaO}-4532$ & Theropithecus atlanticus & -12.7 & -1.5 & 0.709137 \\
\hline \multirow[t]{2}{*}{$\mathrm{AaO}-4549$} & Theropithecus atlanticus & -12.6 & -1.7 & 0.709087 \\
\hline & Average & $-12.4(0.8)$ & $-1.7(0.7)$ & $\begin{array}{l}0.7090566 \\
(0.000103)\end{array}$ \\
\hline
\end{tabular}


Table 2 Carbon and oxygen stable isotope values, and strontium isotope ratios, of fauna analyzed from Tighennif, Algeria, dated to ca. 1.0 Ma. Specimens are accessioned in the Muséum National d'Histoire Naturelle, Paris, France; uncatalogued specimens are designated "UC".

\begin{tabular}{|l|l|l|l|l|l|}
\hline Accession Number & Taxon & $\delta^{13} \mathrm{C}$ & $\delta^{18} \mathrm{O}$ & ${ }^{87} \mathrm{Sr} /{ }^{86} \mathrm{Sr}$ & Source \\
\hline UC & $\begin{array}{l}\text { Ceratotherium } \\
\text { mauritanicum }\end{array}$ & -11.8 & -7.3 & & This Study \\
\hline 84600 & $\begin{array}{l}\text { Ceratotherium } \\
\text { mauritanicum }\end{array}$ & -11.5 & -1.5 & & $\begin{array}{l}\text { Bocherens et al., } \\
\text { MNHN 1931-8-39 }\end{array}$ \\
\hline $\begin{array}{l}\text { Ceratotherium } \\
\text { mauritanicum }\end{array}$ & -10.0 & -6.5 & & This Study \\
\hline
\end{tabular}




\begin{tabular}{|c|c|c|c|c|c|}
\hline MNHN 1954-7-13 & $\begin{array}{l}\text { Ceratotherium } \\
\text { mauritanicum }\end{array}$ & -11.6 & -7.8 & & This Study \\
\hline MNHN 1955-13-117 & $\begin{array}{l}\text { Ceratotherium } \\
\text { mauritanicum }\end{array}$ & -11.6 & -8.8 & & This Study \\
\hline MNHN 1956-12-125 & $\begin{array}{l}\text { Ceratotherium } \\
\text { mauritanicum }\end{array}$ & -11.3 & -7.9 & & This Study \\
\hline $\mathrm{UC}$ & $\begin{array}{l}\text { Connochaetes tauinus } \\
\text { prognu }\end{array}$ & -9.7 & -5.9 & & This Study \\
\hline UC & $\begin{array}{l}\text { Connochaetes tauinus } \\
\text { prognu }\end{array}$ & -10.5 & -4.3 & & This Study \\
\hline UC & $\begin{array}{l}\text { Connochaetes tauinus } \\
\text { prognu }\end{array}$ & -10.2 & -4.1 & & This Study \\
\hline UC & $\begin{array}{l}\text { Connochaetes tauinus } \\
\text { prognu }\end{array}$ & -11.5 & -8.0 & & This Study \\
\hline 84700 & $\begin{array}{l}\text { Connochaetes tauinus } \\
\text { prognu }\end{array}$ & -8.4 & -2.5 & & $\begin{array}{l}\text { Bocherens et al., } \\
1996\end{array}$ \\
\hline 84800 & $\begin{array}{l}\text { Connochaetes tauinus } \\
\text { prognu }\end{array}$ & -12.5 & -3.0 & & $\begin{array}{l}\text { Bocherens et al., } \\
1996\end{array}$ \\
\hline 63900 & Equus mauritanicus & -11.3 & -1.7 & & $\begin{array}{l}\text { Bocherens et al., } \\
1996\end{array}$ \\
\hline 84500 & Equus mauritanicus & -10.9 & -1.4 & & $\begin{array}{l}\text { Bocherens et al., } \\
1996\end{array}$ \\
\hline TER 686 & Equus mauritanicus & -10.7 & -5.8 & & This Study \\
\hline TER 690 & Equus mauritanicus & -10.9 & -4.0 & 0.709281 & This Study \\
\hline TER 693 & Equus mauritanicus & -11.1 & -5.6 & 0.709085 & This Study \\
\hline TER 712 & Equus mauritanicus & -11.2 & -5.8 & 0.709509 & This Study \\
\hline TER 717 & Equus mauritanicus & -11.1 & -6.1 & & This Study \\
\hline TER 794 & Equus mauritanicus & -10.6 & -6.3 & 0.709403 & This Study \\
\hline
\end{tabular}




\begin{tabular}{|c|c|c|c|c|c|}
\hline TER 807 & Equus mauritanicus & -11.2 & -6.0 & 0.709102 & This Study \\
\hline UC & Gazella sp. & -12.2 & -3.1 & 0.709248 & This Study \\
\hline $\mathrm{UC}$ & Gazella sp. & -12.3 & -3.1 & 0.709181 & This Study \\
\hline UC & Gazella sp. & -10.3 & -2.6 & 0.709240 & This Study \\
\hline $\mathrm{UC}$ & Gazella sp. & -12.7 & -5.5 & 0.709138 & This Study \\
\hline UC & Gazella sp. & -11.8 & -3.0 & 0.709139 & This Study \\
\hline $\mathrm{UC}$ & Hippopotamus sirensis & -12.5 & -10.7 & 0.708946 & This Study \\
\hline 63700 & Hippopotamus sirensis & -12.0 & -5.3 & & $\begin{array}{l}\text { Bocherens et al., } \\
1996\end{array}$ \\
\hline 63800 & Hippopotamus sirensis & -10.6 & -4.0 & & $\begin{array}{l}\text { Bocherens et al., } \\
1996\end{array}$ \\
\hline 64000 & Hippopotamus sirensis & -10.0 & -4.0 & & $\begin{array}{l}\text { Bocherens et al., } \\
1996\end{array}$ \\
\hline 84400 & Hippopotamus sirensis & -9.5 & -4.9 & & $\begin{array}{l}\text { Bocherens et al., } \\
1996\end{array}$ \\
\hline $\begin{array}{l}\text { MNHN 1955-13- } \\
1036\end{array}$ & Hippopotamus sirensis & -11.4 & -8.3 & 0.709381 & This Study \\
\hline MNHN 1955-13-774 & Hippopotamus sirensis & -11.3 & -8.3 & 0.709137 & This Study \\
\hline MNHN 1955-13-762 & Hippopotamus sirensis & -11.1 & -9.1 & & This Study \\
\hline MNHN 1955-13-237 & Hippopotamus sirensis & -10.9 & -9.0 & 0.709077 & This Study \\
\hline TER 1701 & $\begin{array}{l}\text { Theropithecus oswaldi } \\
\text { leakeyi }\end{array}$ & -5.9 & -4.4 & 0.708735 & This Study \\
\hline TER 1789 & $\begin{array}{l}\text { Theropithecus oswaldi } \\
\text { leakeyi }\end{array}$ & -12.0 & -1.9 & & This Study \\
\hline TER 1791 & $\begin{array}{l}\text { Theropithecus oswaldi } \\
\text { leakeyi }\end{array}$ & -11.7 & -3.7 & & This Study \\
\hline
\end{tabular}




\begin{tabular}{|l|l|l|l|l|l|}
\hline TER 1792 & $\begin{array}{l}\text { Theropithecus oswaldi } \\
\text { leakeyi }\end{array}$ & -12.4 & -2.8 & 0.709339 & This Study \\
\hline TER 1793 & $\begin{array}{l}\text { Theropithecus oswaldi } \\
\text { leakeyi }\end{array}$ & -11.7 & -1.1 & 0.708806 & This Study \\
\hline TER 1795 & $\begin{array}{l}\text { Theropithecus oswaldi } \\
\text { leakeyi }\end{array}$ & -13.4 & -2.2 & & This Study \\
\hline TER 1798 & $\begin{array}{l}\text { Theropithecus oswaldi } \\
\text { leakeyi }\end{array}$ & -11.0 & -3.9 & 0.709120 & This Study \\
\hline TER 1799 & $\begin{array}{l}\text { Theropithecus oswaldi } \\
\text { leakeyi }\end{array}$ & -12.2 & -4.2 & 0.709291 & This Study \\
\hline TER 1801 & $\begin{array}{l}\text { Theropithecus oswaldi } \\
\text { leakeyi }\end{array}$ & -11.0 & -4.3 & 0.708816 & This Study \\
\hline TER 1806 & $\begin{array}{l}\text { Theropithecus oswaldi } \\
\text { leakeyi }\end{array}$ & -11.0 & -2.2 & 0.708737 & This Study \\
\hline TER 1808 & $\begin{array}{l}\text { Theropithecus oswaldi } \\
\text { leakeyi }\end{array}$ & -12.1 & -1.8 & 0.709373 & This Study \\
\hline
\end{tabular}

Table 3 Carbon and oxygen stable isotope values of Theropithecus gelada. Specimens from Guassa are accessioned in the National Museum of Ethiopia, whereas those from near Debre Birhan are housed in the Laboratory for Human Evolutionary Studies, University of California, Berkeley. To account for the Suess effect, raw $\delta^{13} \mathrm{C}$ values were calibrated to pre-industrial conditions $\left(\delta^{13} \mathrm{C}_{1750}\right)$, see text for details.

\begin{tabular}{|l|l|l|l|l|l|l|}
\hline Sample ID & Source & Year of death & $\delta^{13} \mathrm{C}$ & $\delta^{13} \mathrm{C}_{1750}$ & $\delta^{18} \mathrm{O}$ & Source \\
\hline MCA 442 & Guassa Plateau & $\begin{array}{l}\sim 2010(2007- \\
2014)\end{array}$ & -13.3 & -11.3 & -0.3 & This Study \\
\hline MCA 444 & Guassa Plateau & $\begin{array}{l}\sim 2010(2007- \\
2014)\end{array}$ & -13.8 & -11.8 & -0.4 & This Study \\
\hline MCA 601 & Guassa Plateau & $\begin{array}{l}\sim 2010(2007- \\
2014)\end{array}$ & -13.6 & -11.6 & -0.9 & This Study \\
\hline
\end{tabular}




\begin{tabular}{|c|c|c|c|c|c|c|}
\hline MCA 604 & Guassa Plateau & $\begin{array}{l}\sim 2010(2007- \\
2014)\end{array}$ & -13.9 & -11.9 & -1.0 & This Study \\
\hline MCA 631 & Guassa Plateau & $\begin{array}{l}\sim 2010 \text { (2007- } \\
\text { 2014) }\end{array}$ & -13.7 & -11.7 & 0.8 & This Study \\
\hline MCA 632 & Guassa Plateau & $\begin{array}{l}\text { 2010 (2007- } \\
2014)\end{array}$ & -12.8 & -10.8 & 0.0 & This Study \\
\hline T. gelada1 & $\begin{array}{l}\text { "near Debre } \\
\text { Birhan" }\end{array}$ & 1974-1975 & -6.4 & -5.5 & 0.5 & This Study \\
\hline T. gelada2 & $\begin{array}{l}\text { "near Debre } \\
\text { Birhan" }\end{array}$ & 1974-1975 & -6.6 & -5.7 & 2.0 & This Study \\
\hline T. gelada3 & $\begin{array}{l}\text { "near Debre } \\
\text { Birhan" }\end{array}$ & 1974-1975 & -6.7 & -5.8 & 1.9 & This Study \\
\hline T.gelada4 & $\begin{array}{l}\text { "near Debre } \\
\text { Birhan" }\end{array}$ & 1974-1975 & -7.8 & -6.9 & 1.1 & This Study \\
\hline T.gelada5 & $\begin{array}{l}\text { "near Debre } \\
\text { Birhan" }\end{array}$ & 1974-1975 & -6.8 & -5.9 & 1.6 & This Study \\
\hline ET05-SMN-06 & Simien Mountains & 2000 & -10.2 & -8.5 & & $\begin{array}{l}\text { Levin et al., } \\
2008\end{array}$ \\
\hline
\end{tabular}




\section{Figure legends}

Fig. 1. Selective graminivores such as Gazella thomsonii are often depleted ${ }^{13} \mathrm{C}$ relative to bulkfeeding graminivores such as Connochaetes taurinus and Equus burchellii inhabiting the same ecosystem. Data source: Cerling et al. (2015), but $\delta^{13} \mathrm{C}$ values are adjusted to reflect preindustrial levels of atmospheric $\mathrm{CO}_{2}$.

Fig. 2. Progressive increase in the bulk-feeding behaviour of Theropithecus through the PlioPleistocene. Bars represent the mean difference $(\Delta)$ and 1 SD (whiskers) between the $\delta^{13} \mathrm{C}$ values of Theropithecus in a given and coeval (A) alcelaphines and (B) equids, ordered by time interval. Data used are available in Table S1 and raw values in supplemental dataset.

Fig. 3. Larger species of Theropithecus engaged in greater bulk-feeding behavior. Median body mass of Theropithecus in a given assemblage plotted as a function of mean difference $(\Delta)$ in $\delta^{13} \mathrm{C}$ values between it and coeval (A) alcelaphines and (B) equids. Key to names: AAO: Ahl al Oughlam; ASB: Asbole; HAD: Hadar (SHM, DDM, KHM); KAJ: Kanjera South; KAN: Kanapoi; KBS: KBS, Koobi Fora; LOK: Lokochot, Koobi Fora; MAK: Makapansgat; MIR: Mirzapur, Indian Siwaliks; MU_L: Middle and Lower Lomekwi, Nachukui; NKT: Nariokotome, Nachukui; OG: Olduvai Gorge; OK: Okote, Koobi Fora; SWRT: Swartkrans; TB: Tulu Bor, Koobi Fora (T. darti); TB_LL: Tulu Bor, Koobi Fora / Lower Lomekwi, Nachukui (T. brumpti); TER: Tighennif; UB: Upper Burgi, Koobi Fora; WM: Woranso-Mille.

Fig. 4. Variation in the strontium isotope ratios of North African theropiths increased significantly between the fossil assemblages of (A) Ahl al Oughlam at 2.5 Ma (T. atlanticus) and (B) Tighennif at 1.0 Ma (T. oswaldi leakeyi), whereas that of Gazella did not. Dashed lines 
represent the measured ${ }^{87} \mathrm{Sr} /{ }^{86} \mathrm{Sr}$ ratio of seawater for each time interval (Hess et al., 1986) and the interpolated bioavailable ${ }^{87} \mathrm{Sr} /{ }^{86} \mathrm{Sr}$ ratio for each location (Bataille et al., 2020). The "sea spray effect" is evident for both coastal assemblages. This effect refers. Diamonds are means, whiskers are $1 \mathrm{SD}$.

Fig. 5. Leaf fracture toughness of individual plants varied as a function of plant growth form but differ between $\mathrm{C}_{3}$ and $\mathrm{C}_{4}$ grasses. Diamonds are means; whiskers are $1 \mathrm{SD}$. Differential lettering represents a statistical difference based on Tukey HSD post-hoc tests. Raw individual values are available as a supplemental data set, whereas plant species means are available in Table S1.

Fig. 6. Cercopithecid primates are uniformly diurnal and geladas begin feeding soon after sunrise. This figure illustrates equatorial daylight hours and the feeding duration of $T$. gelada during the wet season (when food is denser, more digestible, and intake rates are lower) and the dry season (when food is patchier, less digestible, and intake rates are higher; Iwamoto, 1993; Hunter, 2001; Venkataraman et al., 2014). If we assume that tradeoffs in food intake rate and digestibility extend to the fossil past, and if we extrapolate this pattern to larger body sizes (source: Table S1) and their attendant basal metabolic rates (assumptions and calculations in Lee and Foley, 1993), it is evident that species with a median mass exceeding $30 \mathrm{~kg}$ cannot turn to lower-quality foods, as geladas do, and preserve a strictly diurnal activity pattern. We view body masses $>30 \mathrm{~kg}$ as an evolutionary trap because survival depends on the continuous availability of the highest-quality food patches ('grazing lawns'). Our model suggests that T. oswaldi leakeyi reached the viable limit of bulk-feeding graminivory for any primate, devoting nearly all of their daylight hours to feeding, leaving scant time for allogrooming ( $\sim 2$ hours per day for T. gelada) or other essential behaviors. 